\title{
A GYOMORRÁK KEZELÉSÉNEK AKTUALITÁSAI \\ II. rész. A gyógyszeres kezelés patológiai alapjai és háttere, minőségbiztosítás a patológiában
}

\author{
Kulka Janina ${ }^{1}$, Szirtes Ildikó ${ }^{1}$, Szász A. Marcell ${ }^{1}$, Kupcsulik Péter ${ }^{2}$, \\ Kenessey István ${ }^{1}$, Lotz Gábor ${ }^{1}$, Tímár József ${ }^{1}$ \\ Semmelweis Egyetem, ${ }^{1}$ II. sz. Patológiai Intézet, ${ }^{2}$ I. sz. Sebészeti Klinika, Budapest
}

\begin{abstract}
A gyomorrák célzott, HER2-ellenes terápiájának bevezetése a klinikai gyakorlatba nagy elörelépést jelent a kezelés és a betegség prognózisa szempontjából. A célzott terápia azonban csak úgy válhat igazán sikeressé, ha a HER2-meghatározás módszertana megfelelöen validált, szigorú kritériumok alapján történik. Különösen fontos ezt szem elött tartani azért is, mert a gyomorrákok egy részében kizárólag biopsziákból történik a diagnosztika, amelyek esetében a HER2-meghatározást különösen tapasztalt patológusoknak, és gyakorlott, standardizált módszereket alkalmazó laboratóriumoknak szabad csak végeznie. Mint diagnosztikus értékü és terápiás döntést befolyásoló vizsgálat, alapvető fontosságú a minden tekintetben megfelelö minöség, amelynek biztositéka a rendszeres külső technikai és interpretációs minöségellenörzés. A hazai patológusok a Roche Magyarország Kft. segítségével szinte a célzott kezelés hazai bevezetésével egyidóben lebonyolitottak egy minőségellenörző körvizsgálatot, amelyben a résztvevó laboratóriumok döntő többségének alkalmassága bizonyosodott be. Magyar Onkológia 54: 343-350, 2010
\end{abstract}

Kulcsszavak: gyomorrák, célzott terápia, HER2, minőségbiztosítás

The administration of targeted therapy of gastric carcinoma is a very important recent improvement of its treatment and prognosis. The basis of the successful treatment is the excellent quality of pathology, now including HER2 testing: the use of validated methods and strict criteria. This is especially important if we consider that many gastric cancers are diagnosed in small biopsy material, in which HER2 testing is challenging. This requires standardized, validated methods and experienced pathologists. Being of diagnostic and predictive significance, high quality of both the technique and the interpretation of the test is mandatory. In order to achieve general high quality in this field, technical and interpretation external quality control of HER2 testing is necessary. Hungarian pathologists with the help of Roche Hungary Ltd. completed an external quality control round which showed that most of the participating laboratories are able. Kulka J, Szirtes I, Szász AM, Kupcsulik P, Kenessey I, Lotz G, Tímár J. Pathology background of targeted therapy; quality control in pathology. Hungarian Oncology 54: 343-350, 2010

Keywords: gastric cancer, targeted therapy, HER2, quality control

\section{EPIDEMIOLÓGIA}

A gyomorrák, mint azt az előzőekben láttuk, hazánkban a 9. leggyakoribb rosszindulatú daganat, halálozás tekintetében pedig a 4 . leggyakoribb rákos megbetegedés (4) (1. táblázat). Legfontosabb etiológiai faktora Magyarországon a Helicobacter pylori-fertőzés.
Közlésre érkezett: 2010. november 10 .

Elfogadva: 2010. november 19.

Levelezési cím:

Dr. Kulka Janina, Semmelweis Egyetem II. sz. Patológiai Intézet, 1091 Budapest,

Üllői út 93.

Telefon/Fax: (06-1) 216-6921, e-mail: kj@korb2.sote.hu

Rövidítések: TMA: tissue microarray = szöveti mikrosorozat; APC: adenomatosus polyposis coli; c-met: mesenchymal epithelial transition factor; DCC: deleted in colon cancer; K-ras: Kirsten rat sarcoma viral oncogene homolog; DAPK: death associated protein kinase; MGMT: O-6-methylguanine-DNA methyltransferase; COX2: cyclooxygenase 2; EGFR: epidermal growth factor receptor; c-myc: myelocytomatosis viral oncogene homolog; IHC: immunhisztokémia; TPR: translocated promoter region/tumor potentiating region 

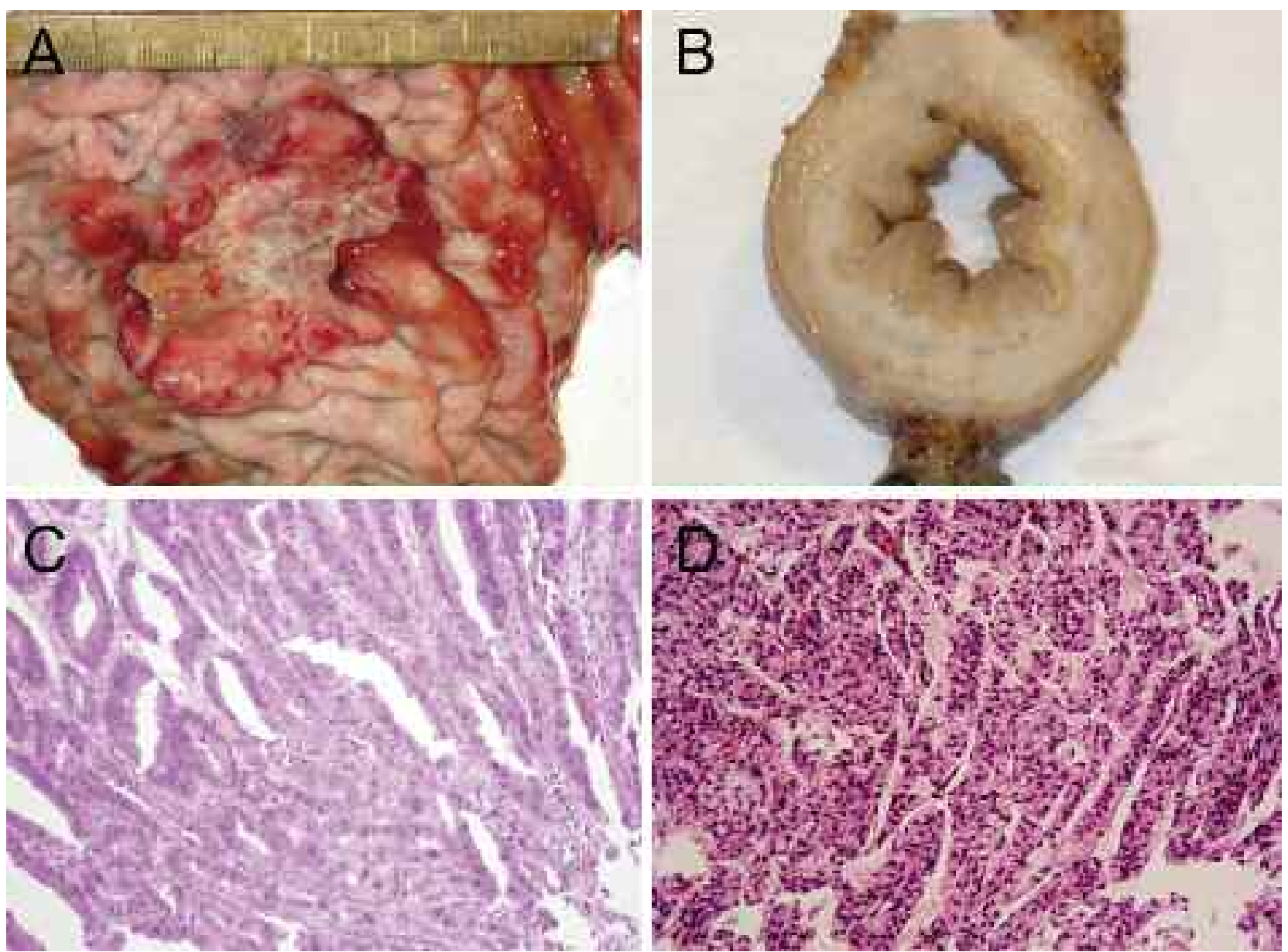

1. ábra. Intestinalis és diffúz típusú gyomorrák makroszkópos ( A és B) és mikroszkópos (C és D) képe

1. táblázat. A gyomorrák epidemiológiája hazánkban, 2005 (4)

\begin{tabular}{lccc} 
& Teljes populáció & Férfi & Nő \\
\hline Incidencia & 2354 & 1326 & 1028 \\
Halálozás & 1722 & 984 & 738 \\
\hline
\end{tabular}

\section{PATOLÓGIA}

A gyomorrák-esetek igen jelentős százalékában a betegség diagnosztikája kis biopsziás mintákból történik. Az inoperábilis primer gyomorrákokat gyakran csak endoszkópos biopsziás minták alapján diagnosztizáljuk, ami előrevetíti azt a problémát, hogy esetleges differenciáldiagnosztikai kérdések eldöntése, vagy egyéb kiegészítő vizsgálatok számára nagyon limitált volumenú szövettani minta áll csak rendelkezésre.

A gyomorrák rákmegelőző állapotai a krónikus gastritis, intestinalis metaplasia, in situ gyomorrák (noninvazív high-grade neoplasia) szekvenciában szereplő elváltozások. A két fő szövettani alcsoport klinikopatológiai jellemzői eltérőek (2. táblázat) (8). Az intestinalis típusú forma általában atrophiás gastritis talaján keletkezik, exofitikus, gyakran exulcerált. Érdekes, hogy gyakoribb férfiakban, és egy kicsit magasabb az átlagéletkor, mint a diffúz típus esetében. A diffúz gyomorrák eseteiben a férfi-nő arány kiegyenlített. Mai tudásunk szerint a diffúz típus rákmegelőzô állapotai a foveoláris hyperplasia és a krónikus gastritis. Makroszkóposan, szemben az intestinalis típusú rák exofitikusan növekedő formájával, gyakran linitis plastica képében jelentkezik. Az intestinalis típus változó mértékben differenciált adenocarcinoma, amelyben a daganatsejtek nyákot termelhetnek, a nyák általában a mirigyek lumenében helyezkedik el. A diffúz típus esetében mirigyképzési tendencia nincs, vagy csak elvétve látható, és a nyák a daganatsejtek citoplazmájában halmozódik fel. A két daganattípus eltérő proliferációs aktivitást mutat, ez az intestinalis típusban általában magas, míg a diffúz típusban alacsony. Ezzel szemben a desmoplasia, a masszív kötőszövetes stroma a diffúz típus jellemzője. Feltûnő még, hogy az intestinalis formában a daganatot infiltráló limfoid sejtek száma magasabb, és az eozinofil granulociták is nagyobb számban vannak jelen, mint a diffúz formában. Mindkét szövettani típus esetében az első áttétek a locoregionalis nyirokcsomókban alakulnak ki. A peritonealis disseminatio elsősorban a diffúz típusban fordul elő, és elsősorban erre jellemző az ováriumokban történő áttétképzés, az ún. 
2. táblázat. A gyomorrák két fö típusának jellemzői

\begin{tabular}{|c|c|c|c|}
\hline & & Intestinalis típus & Diffúz típus \\
\hline \multicolumn{2}{|l|}{ Átlagéletkor } & 55 év & 48 év \\
\hline \multicolumn{2}{|c|}{ Férfi/nő arány } & $2: 1$ & $1: 1$ \\
\hline \multirow{2}{*}{\multicolumn{2}{|c|}{ Rákmegelőző állapot }} & intestinalis metaplasia, & foveolaris hyperplasia, \\
\hline & & atrophiás gastritis & gastritis chronica \\
\hline \multicolumn{2}{|c|}{ Makroszkópia } & exofitikus, exulcerált & linitis plastica \\
\hline \multirow{2}{*}{\multicolumn{2}{|c|}{ Szövettan }} & mirigyképzés, & mirigyképzés nincs, \\
\hline & & nyák főleg a lumenben & $\begin{array}{l}\text { nyák a sejtek citoplazmájában (pe- } \\
\text { csétgyúrú alak) }\end{array}$ \\
\hline & Proliferációs index & magas & alacsony \\
\hline & Desmoplasia & - & + \\
\hline & TIL (tumorinfiltráló limfociták) & + & - \\
\hline & eozinofilek & + & $+/-$ \\
\hline & grading & jól differenciált & rosszul differenciált \\
\hline & & közepesen differenciált & \\
\hline & & rosszul differenciált & \\
\hline \multirow[t]{4}{*}{ Áttétképzés } & Limfogén & ++ & ++ \\
\hline & Peritoneális & $+1-$ & +++ \\
\hline & Kruckenberg & $+1-$ & +++ \\
\hline & Egyéb szervi & máj, tüdő & \\
\hline
\end{tabular}

Kruckenberg-tumor, míg az intestinalis forma távoli szervi áttétként elsősorban májáttéteket képez.

\section{MOLEKULÁRIS PATOLÓGIA}

A gyomorrák etiológiájában kiemelkedő szerepe van a Helicobacter pylori-fertőzésnek és az ezt követő krónikus gastritisnek. A molekuláris patológiai vizsgálatok kimutatták, hogy a két szövettani típusban eltérő génhibák halmozódnak fel: az intestinalis típusban korán megtörténik bizonyos szuppresszor gének - mint az APC - metilációja, a kialakult primer tumorok esetében jelen lehet a HER2 gén fokozott expressziója, amely gyakran HER2-génamplifikációt jelent. A diffúz forma esetében a c-met onkogén amplifikációja mutatható ki, és telomerázaktiválódás is jelen van. Fontos eltérés a két forma között még, hogy az intestinalis típusban nem túl nagy gyakorisággal K-ras-mutáció figyelhetó meg, szemben a diffúz formával, amely inkább p53mutációt mutat. Ez utóbbi típusban emellett metilációs zavarok mutathatók ki, melyek érintik a DAPK-t, a K-ras-t, a retinolsav-receptort, MGMT-t, míg az intestinalis formában a p16 onkoszuppresszor gén mellett a COX-2, a mismatch-repair rendszer, az APC és a DCC érintett. A gyomorcarcinomák progressziós markerei között megemlítendő az EGFR gén fokozott expressziója, amely kedvezőtlen prognózissal jár. A gyomorrákok mintegy 40\%-ában a c-myc onkogén amplifikációja is kimutatható, amely fokozottabb áttétképző hajlammal jár együtt. A c-met onkogén expressziójának fokozódása a regionális nyirokcsomóáttétek és a peritonea- lis szóródás kialakulásának markere. Ezzel kapcsolatban érdemes megjegyezni, hogy a daganatok egy kis hányadában a c-met onkogén transzlokációja is bekövetkezik, melynek eredményeként TPR-MET fúziós gén keletkezik (9).

\section{A HER2 GÉN FOKOZOTT EXPRESSZIÓJA}

Mint korábban említettük, a gyomorrák is azon daganatok sorát gyarapítja, amelyekben lényeges genetikai eltérés lehet a HER2 gén amplifikációja. Az emlőrák esetében ennek gyakorisága 20\%, tüdő-adenocarcinomákban 10\%, a nyelőcső laphámrákjai között 15-20\%, míg a gyomorrákok esetében az amplifikáció gyakorisága a különböző irodalmi adatok szerint 10-20\% között van $(2,5,6)$. A HER2 kimutatása az elmúlt 10 évben rutin módszerré vált a molekuláris patológiában, amelyet az emlőrákok HER2-státusának meghatározására dolgoztak ki, és standardizáltak. A gyomorrákok esetében is ezt a módszertant alkalmazták éveken át, és így a gyomorrákok igen különböző hányadában, de konzekvensen jelezték a vizsgálatok a HER2 protein fokozott expresszióját, illetve a génamplifikáció jelenlétét (2. ábra A és C). A vizsgálatok egymásnak kissé ellentmondó adatait elemezve, egy német munkacsoport rájött arra, hogy a gyomorrákok esetében az emlőrák HER2-diagnosztikájának elvét nem lehet minden változtatás nélkül alkalmazni, aminek két legfontosabb oka az alábbiakban keresendő (3): az egyik ok, hogy a HER2 fehérje gyomorrákok esetében gyakran nem kör- 

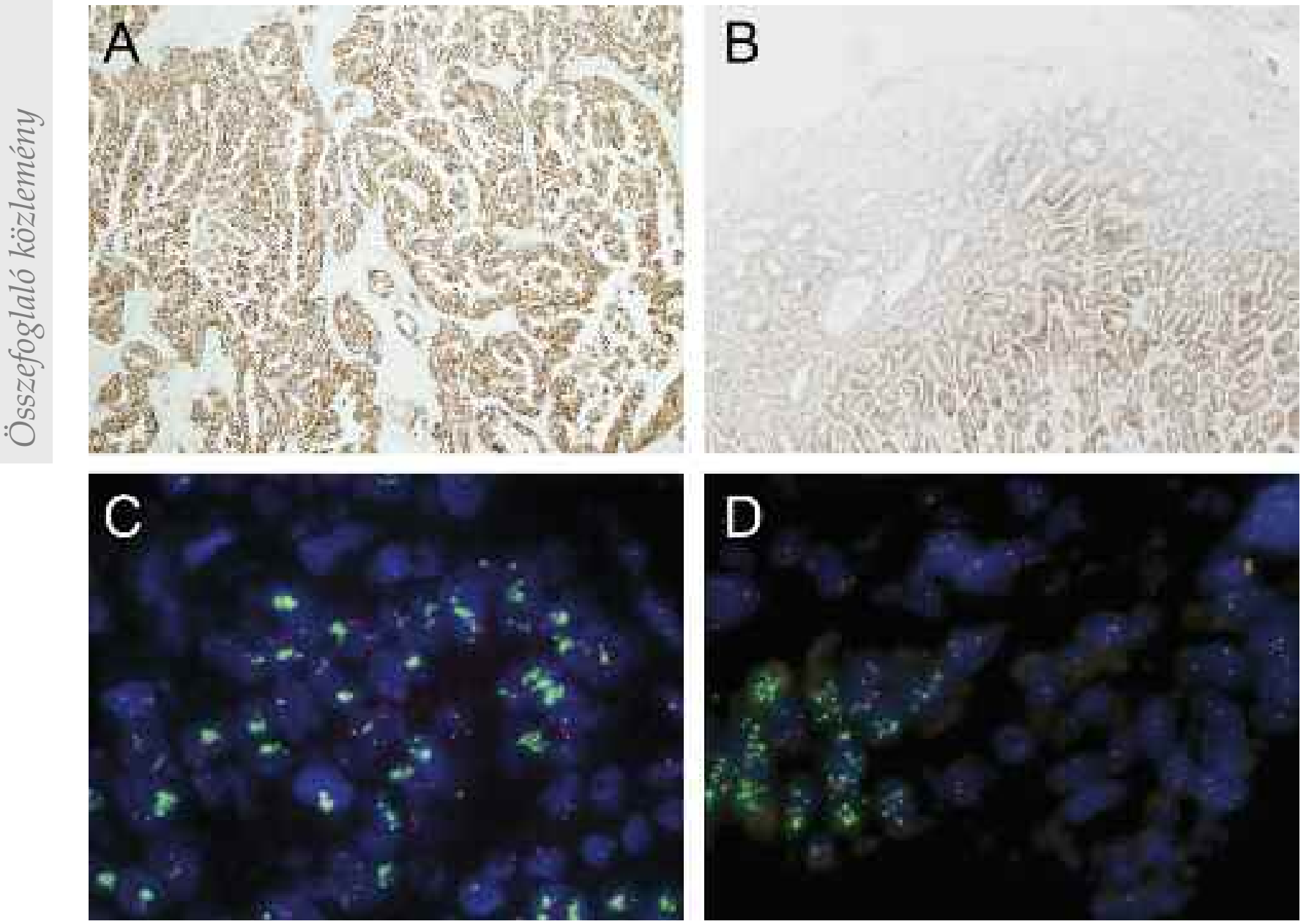

2. ábra. HER2 immunhisztokémiai reakció és FISH intestinalis típusú gyomorrák esetében;

A) Kifejezett intenzitású bazolaterális lokalizációjú membránreakció (3+), egyértelmúen HER2-pozitív eset.

B) Heterogén immunhisztokémiai reakció. C) Egyértelmú HER2-génamplifikáció a FISH-reakcióban. D)Heterogenitást mutató HER2 FISH

körös membránlokalizációjú, mert nyáktermelő daganatsejtek lévén a luminális membránszakaszon a HER2 nem expresszálódik. Ettôl még a daganatsejtek intenzív laterális vagy bazolaterális membránjelölődést mutathatnak, és ez ugyanolyan prediktív értékú, mint emlőrák esetében a körkörös, azonos intenzitású jelölődés. A másik sajátossága a gyomorrákoknak az emlőrákkal szemben, hogy a vizsgálatok és a metaanalízisek alapján úgy tûnik, hogy meglehetôsen gyakran egymástól függetlenül lehet jelen a HER2 fehérje fokozott expressziója és a HER2 gén sokszorozódása, vagyis előfordul génamplifikáció fokozott fehérjeexpresszió nélkül, és előfordul fokozott fehérjeexpresszió génamplifikáció nélkül is. Kidolgozták a gyomorrákok HER2-státusának megállapításához a patológiai és molekuláris patológiai értékelések szabályait az emlőrákoknál már megismert $0,1+, 2$ + és $3+$ kategóriákat használva, ahol a 0 és $1+$ kategóriák a HER2-negatív daganatokat jelzik, a $3+$ a HER2-pozitív daganatot, míg a $2+$ a kérdéses, in situ hibridizációs technikával továbbvizsgálandó kategóriát jelöli. Ezeket a kategóriákat aztán nagyszámú gyomorrákmintán validálták az elmúlt két évben, és igazolták prediktív jelentőségüket a célzott terápia alkalmazásának hatékonyságára vonatkozóan $(1,3,7)$ (3. táblázat).
A gyomorrákok esetében mútéti reszekátumokban az immunhisztokémiai pozitivitási határértéket (szemben az emlőrákos esetekkel) a daganatsejtek 10\%-ának pozitivitásában határozták meg $(1,3,7)$. A kiértékelési módszertan különlegessége a biopsziás minták eltérő értékelése, amelyre emlőrákos esetekben nincs külön útmutató. Gyomorrák esetén azonban a biopsziás mintákban a pozitivitás megállapításához akár 5 daganatsejt membránjához kötött pozitív reakció is elegendő.

Nagyon fontos szem előtt tartani a gyomorrákok HER2-expressziójával kapcsolatosan azt a tényt, hogy a fehérje expressziója nagyon heterogén lehet: negatív területek váltakoznak pozitív területekkel (2. ábra B és D). Ennek két szempontból van gyakorlati jelentősége. A jelenleg érvényes irányelvek nem szabják meg, hogy sebészi reszekátumokban hány kimetszésből (blokkból) történjen HER2-meghatározás, illetőleg felértékelődik a biopsziás minta, mint egy nagyon fontos prediktív vizsgálatra is használható anyag. Az endoszkópos irányelvek szerint minimum 5 biopsziás minta kell, hogy rendelkezésre álljon gyomorrák diagnózisához. Ennek a minimális biopsziaszámnak a megléte a HER2-státus meghatározása esetén is valószínúleg nagy jelentőségú lehet (3. táblázat), hiszen ha alacsony számú biopsziás 
3. táblázat. A HER2-meghatározás standard módszere gyomorcarcinomák esetén

\begin{tabular}{|c|c|c|c|c|}
\hline $\begin{array}{c}\text { Festődés } \\
\text { intenzitásának } \\
\text { foka }\end{array}$ & $\begin{array}{l}\text { Mútéti preparátum - } \\
\text { a festődés jellege }\end{array}$ & $\begin{array}{l}\text { Biopsziás minta - } \\
\text { a festődés jellege }\end{array}$ & $\begin{array}{l}\text { A fokozott } \\
\text { HER2- } \\
\text { expresszió } \\
\text { értékelése }\end{array}$ & 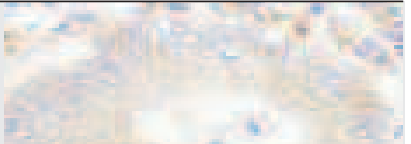 \\
\hline 0 & $\begin{array}{l}\text { Nincs festődés, vagy a } \\
\text { tumorsejtek kevesebb, } \\
\text { mint } 10 \% \text {-ában van } \\
\text { membránfestődés }\end{array}$ & $\begin{array}{l}\text { Nincs festődés, illetve nincs } \\
\text { membránfestődés egyetlen } \\
\text { tumorsejtben sem }\end{array}$ & Negatív & $\rightarrow$ \\
\hline $1+$ & $\begin{array}{l}\text { A tumorsejtek legalább } \\
\text { 10\%-ában halvány/alig } \\
\text { észrevehető membrán- } \\
\text { festődés; a sejtek } \\
\text { festődése csak a } \\
\text { membránjuk egy részén } \\
\text { történik meg }\end{array}$ & $\begin{array}{l}\text { Tumorsejt-csoportok } \\
\text { halvány, vagy alig } \\
\text { észrevehető membrán- } \\
\text { festődése az érintett } \\
\text { tumorsejtek százalékos } \\
\text { arányától függetlenül }\end{array}$ & Negatív & 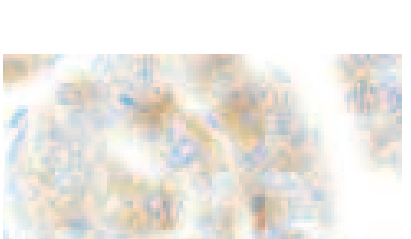 \\
\hline $2+$ & $\begin{array}{l}\text { Enyhe, közepes fokú } \\
\text { egybefüggő bazolaterális } \\
\text { vagy laterális } \\
\text { membránfestődés a } \\
\text { tumorsejtek legalább } \\
\text { 10\%-ában }\end{array}$ & $\begin{array}{l}\text { Tumorsejt-csoportok enyhe } \\
\text { közepes fokú egybefüggő, } \\
\text { bazolaterális, vagy laterális } \\
\text { membránfestődése az érintett } \\
\text { tumorsejtek százalékos } \\
\text { arányától függetlenül }\end{array}$ & Kérdéses & \\
\hline $3+$ & $\begin{array}{l}\text { Erôs, egybefüggő } \\
\text { bazolaterális vagy } \\
\text { laterális membrán- } \\
\text { festődés a tumor } \\
\text { sejtek legalább } \\
\text { 10\%-ában }\end{array}$ & $\begin{array}{l}\text { Tumorsejt-csoportok erős } \\
\text { egybefüggő, bazolaterális, } \\
\text { vagy laterális membrán- } \\
\text { festődése az érintett } \\
\text { tumorsejtek százalékos } \\
\text { arányától függetlenül }\end{array}$ & Pozitív & $\frac{1}{4} \sin x$ \\
\hline
\end{tabular}

mintából történik gyomorrák esetén a HER2 meghatározása, nagy a valószínúsége a nagyfokú heterogenitás miatt annak, hogy a biopsziás minta nem reprezentálja a primer tumort.

\section{HER2-EXPRESSZIÓ HAZAI GYOMORRÁKOS ANYAGBAN}

A Semmelweis Egyetem II. sz. Patológiai Intézetében egy év alatt (2009. január 1. - december 31.) diagnosztizált 97 gyomorrák esetében elvégeztük a HER2-státus meghatározását, majd a reakciót a Hofmann-féle módszerrel értékeltük (9), amely mára standardként elfogadott értékelési séma. A HER2 fehérje kimutatását immunhisztokémiai módszerrel végeztük. A primer antitest az SP3 (Spring Bioscience, Pleasanton, CA, USA) volt, az immunhisztokémiai reakció automatizáltan, standard körülmények között történt (Ventana Benchmark XT, Ventana Medical Systems, Inc., Tucson, AZ, USA). Ezzel párhuzamosan valamennyi esetben elvégeztük a HER2 gén amplifikációjának vizsgálatát, ahol kettős próbát használtunk, a HER2 gén és 17-es kromoszóma centromer régióinak próbáit (ZytoVision ZytoLight (® SPEC HER2/CEN 17 Dual Color Probe Kit), így meg tudtuk határozni az amplifikáció mellett az esetleges poliszómia gyakoriságát is. Ahogy az a 4 . táblázatban látható, a különböző szövettani altípusok közül saját beteganyagunkban is az intestinalis típusú gyomorrákban a leggyakoribb a 3+ intenzitású HER2proteinexpresszió - intézeti eseteinkben közel 14\%. A diffúz gyomorrák eseteiben immunhisztokémiai vizsgálattal egyértelmú HER2-túlexpresszió nem volt ki- mutatható, egy kevert carcinoma esetünk volt HER2pozitív. A $2+$ intenzitású immunhisztokémiai reakciót mutató, kérdéses esetek aránya is az intestinalis formában a leggyakoribb.

A vizsgálatból az is kiderült, hogy a gyomor adenocarcinomái a mi anyagunkban is döntően HER2-negatívak: a daganatok közel 4/5-e HER2-negatív. A $3+$ intenzitású HER2-expressziót mutató gyomorrákok aránya összességében 10\% körül van, és hasonló arányú a $2+$ tumoroké is. Anyagunkban a HER2-amplifikációt mutató daganatok aránya 14\% volt, ezek egy kevert carcinoma kivételével az intestinalis szövettani altípust képviselték. A vizsgálat azonban azt is kimutatta, hogy a gyomorrákok nagyobb százalékában számolni kell poliszómiával is, nagyobb gyakorisággal, mint az amplifikációval, és ennek azért van jelentősége, mert a HER2-poliszómia biológiai vagy klinikai jelentősége gyomorrákban egyelőre kérdéses. Miután ilyen gyakori a poliszómia, a HER2-génamplifikáció meghatározására olyan in situ hibridizációs technológiát kell alkalmazni, ahol a 17-es kromoszóma is jelölődik, hogy el lehessen egyértelmúen választani az amplifikált daganatokat a poliszómiás daganatoktól. Saját vizsgálatunkban megállapítottuk azt is, hogy a HER2 3 + daganatok esetében 100\%-os korreláció mutatkozott a génamplifikációval, míg a HER2 2 + daganatok közül csak két esetben (20\%) lehetett génamplifikációt kimutatni. A 17. kromoszóma poliszómiája a $0,1+, 2+$ intenzitású reakciót mutató daganatokban fordult elő. Mindezek alapján megállapítható volt, hogy amennyiben reprezentatívnak tekintjük a hazai beteganyagra az Intézetünk vizsgált gyomorrák-anyagát, akkor az immunhisztokémiai vizsgálattal HER2-pozitívnak (3+ és $2+$ ) tekinten- 
4. táblázat. A HER2 fehérje- és génexpresszió vizsgálatának eredményei 97 gyomorcarcinoma esetünkben

\begin{tabular}{|c|c|c|c|c|c|c|c|}
\hline Szövettani típus & $\begin{array}{c}\text { SCORE } \\
\text { esetszám }\end{array}$ & $\begin{array}{c}0 \\
(\%)\end{array}$ & $\begin{array}{l}1+ \\
(\%)\end{array}$ & $\begin{array}{l}2+ \\
(\%)\end{array}$ & $\begin{array}{l}3+ \\
(\%)\end{array}$ & $\begin{array}{c}\text { Poliszómia } \\
(\%)\end{array}$ & $\begin{array}{c}\text { Amplifikáció } \\
(\%)\end{array}$ \\
\hline Intestinalis & 58 & $\begin{array}{c}26 \\
(44,8)\end{array}$ & $\begin{array}{c}15 \\
(25,8)\end{array}$ & $\begin{array}{c}9 \\
(15,5)\end{array}$ & $\begin{array}{c}8 \\
(13,8)\end{array}$ & $\begin{array}{c}16 \\
(27,6)\end{array}$ & $\begin{array}{c}12 \\
(20,7)\end{array}$ \\
\hline Diffúz & 22 & $\begin{array}{c}17 \\
(77,3)\end{array}$ & $\begin{array}{c}4 \\
(18,2)\end{array}$ & $\begin{array}{c}1 \\
(4,5)\end{array}$ & 0 & $\begin{array}{c}4 \\
(18,2)\end{array}$ & 0 \\
\hline Kevert & 3 & $\begin{array}{c}2 \\
(66,7)\end{array}$ & 0 & 0 & $\begin{array}{c}1 \\
(33,3)\end{array}$ & $\begin{array}{c}1 \\
(33,3)\end{array}$ & $\begin{array}{c}1 \\
(33,3)\end{array}$ \\
\hline Anaplasticus & 7 & $\begin{array}{c}5 \\
(71,4)\end{array}$ & $\begin{array}{c}2 \\
(28,6)\end{array}$ & 0 & 0 & 0 & 0 \\
\hline NOS & 7 & $\begin{array}{c}7 \\
(100)\end{array}$ & 0 & 0 & 0 & $\begin{array}{c}3 \\
(42,8)\end{array}$ & 0 \\
\hline Összes carcinoma & 97 & $\begin{array}{c}57 \\
(58,8)\end{array}$ & $\begin{array}{c}21 \\
(21,6)\end{array}$ & $\begin{array}{c}10 \\
(10,3)\end{array}$ & $\begin{array}{c}9 \\
(9,3)\end{array}$ & $\begin{array}{c}24 \\
(24,7)^{*}\end{array}$ & $\begin{array}{c}13 \\
(14)^{*}\end{array}$ \\
\hline
\end{tabular}

*4 eset nem vizsgálható

\begin{tabular}{lcccc}
\hline & 0 & $1+$ & $2+$ & $3+$ \\
\hline Kr. 17-poliszómia & $14(26,4)$ & $9(42,8)$ & $4(40)$ & 0 \\
HER2-amplifikáció & $1(1,9)$ & $1(4,8)$ & $2(20 \%)$ & $9(100)$ \\
\hline HER2 IHC-POZITÍlV & & & $19(19,6 \%)$ \\
HER2-AMPLIFIKÁLT & & & $13(14 \%)$ \\
TÉNYLEGESEN HER2-POZITÍV $(2+/ 3+/ \mathrm{A})$ & & $11(11,8 \%)$ \\
\hline
\end{tabular}

dő közel 20\%-os tumorarány mellett a HER2 gén amplifikációja csak 11,8\%-ban igazolódott.

Ezen adatokat érdemes összevetni a nemzetközi adatokkal, ahol is azonos elveket alkalmaztak a gyomorrák HER2-státusának meghatározására. Három ilyen vizsgálat eredményei állnak rendelkezésre, amelyekből kiderül, hogy a hazai adatok közeli korrelációt mutatnak a más országokban - Németországban, Délkelet-Ázsiában - megfigyelt HER2-pozitív gyomorrák incidenciához (5. táblázat).

\section{HAZAI HER2 DIAGNOSZTIKAI KÖRVIZSGÁLAT}

Miután a gyomorrák HER2-státusának meghatározása az emlőrákkal nem teljesen azonos elvek szerint történik, ezeket a különbségeket a gyakorlatban el kell sajátítani a patológiai osztályokon. Célszerûnek látszott egy HER2 validációs körvizsgálat lebonyolítása, amelyet a Magyar Patológusok Társasága és a Patológiai Szakmai Kollégium szervezett a Roche Magyarország Kft. támogatásával. A vizsgálatban 26 hazai patológiai osztály vett részt. A vizsgálathoz 20 gyomorrák mintájából szöveti mikrosorozatot (Histopathology Kft., Pécs) készítettünk a II. sz. Patológiai Intézetben (3. ábra). Az esetek mind az Intézetünkben elvégzett HER2-vizsgálatok szempontjából ismert esetek voltak, mindegyik esetben a génamplifikációs státus is meghatározásra került korábban fluoreszcens in situ hibridizációs módszerrel. A mintákat a résztvevő patológiai osztályok megkapták metszet formájában; saját HER2-fehérjekimutatási módszerüket alkalmazva kellett értékelni a reakció eredményét. A gyomorrákos esetekre érvényes HER2-értékelési séma korábban ismertetésre került. Az osztályokon elvégezték és értékelték a HER2-reakciót, majd a metszeteket visszaküldték, és azt is megjelölték az esetek többségében, hogy milyen primer antitestet használtak a vizsgálat során. Miután az összesen 560 kis metszetből a metszés és a reakciók során volt veszteség, összesen 534 értékelhető minta szerepelt a vizsgált anyagban. Ezeknek a HER2-reakcióknak a kiértékelése során 6\%-ban fordult elő eltérés; a megítélés, hogy pozitív (score 3 vagy 2 ), vagy negatív (score 1 vagy 0 ) az adott daganat, csak 3\%-os eltérést mutatott. Amennyiben a HER2-pozitivitás, ill. -negativitás megállapítása szem-

5. táblázat. Saját adataink a nemzetközi, közölt vizsgálatok adatainak tükrében

\begin{tabular}{|c|c|c|c|c|}
\hline & FISH pozitív & IHC $2+$ & IHC $3+$ & IHC pozitív \\
\hline SE II. sz. Patológiai Intézet & $14 \%$ & $10,3 \%$ & $9,3 \%$ & $19,6 \%$ \\
\hline Hofmann & $17,3 \%$ & $12,5 \%$ & $12,5 \%$ & $25 \%$ \\
\hline TOGA & NA & $12 \%$ & $11 \%$ & $23 \%$ \\
\hline Rüschoff & NA & - & - & $22,8 \%$ \\
\hline
\end{tabular}




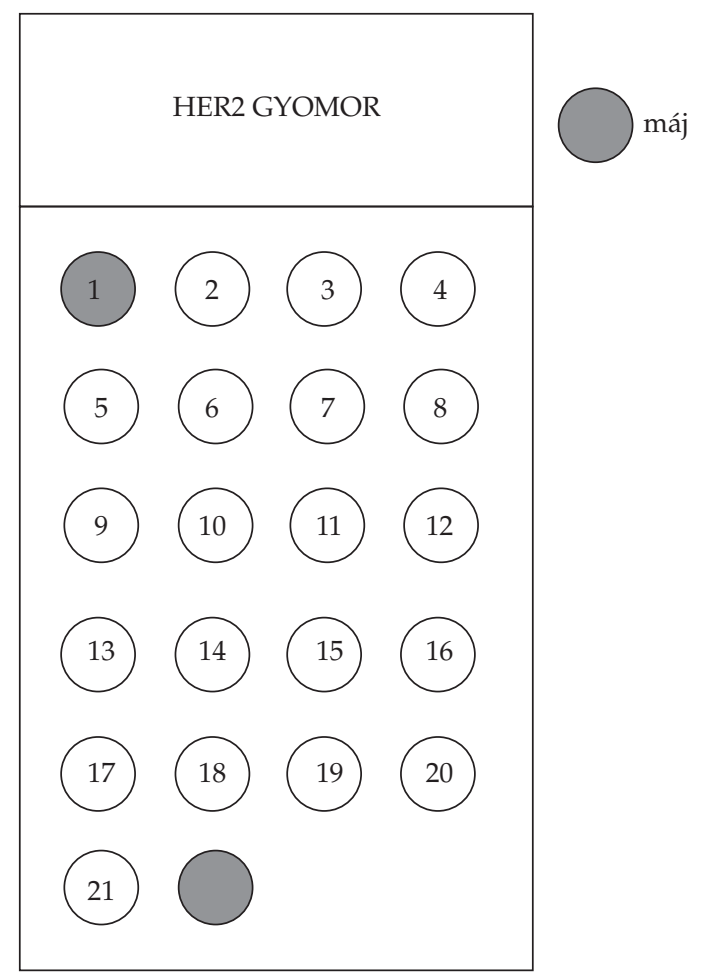

3. ábra. A HER2-körvizsgálathoz készített szöveti mikrosorozat metszetének sémás rajza

pontjából értékeljük a körvizsgálatot, a laboratóriumok fele 90\%-os találati arányt ért el, közel 40\%-uk 95\%-os teljesítményt mutatott, ami igen jónak mondható. A központi értékeléssel 85-89\%-ban egyező értékelést 7 laboratórium adott, 4 laboratórium értékelése 80-85\%ban és 1 laboratórium értékelése 76,7\%-ban egyezett a központi (és egyben a többségi) véleménnyel (4. ábra). A 90\% feletti egyező értékelést adó laboratóriumok megfelelnek a nemzetközi elvárásoknak, és ezért alkalmasak gyomorrákos esetek diagnosztikus HER2 immunhisztokémiai vizsgálatok elvégzésére. A 90\% alatti egyezést mutató laboratóriumok esetében az elemzés kitért arra, hogy az értékelési hibák miből eredhettek: megállapítható volt, hogy fele-fele arányban interpretációs, ill. technológiai problémák álltak ezek hátterében.

Az osztályok különböző primer antitesteket használtak, azonban az értékelés felfedte, hogy a HER2 immunhisztokémiai vizsgálat sikeressége független volt a primer antitest típusától. A körvizsgálatban standardként a DAKO HercepTest (DAKO A/S, Glostrup, Dánia) reakciót használtuk, ezt vetettük össze a PATHWAY 4B5 nyúl monoklonális antitesttel (Ventana Medical Systems) végzett reakció eredményével, automata festőrendszert használva. Ebből megállapítható volt, hogy a 4B5 antitesttel a körvizsgálatban használt TMA metszeten végzett reakció 10\%-ban tért el a HercepTesttel végzettől a gyomorrákok HER2-proteinexpressziójának detektálásában. Egyetlen esetben a pozitivitás-negativitás kérdésében volt eltérés (HercepTest: $2+$, 4B5: 1+, FISH-negatív eset), egy esetben pedig a negativitás mértékében (HercepTest: 1+,4B5: 0). Mind- két esetben a 4B5 antitest volt kevésbé érzékeny, tehát alacsonyabb mértékú proteinexpressziót detektált az adott daganatban. A két antitesttel végzett reakciók és a FISH eredményét összevetve megállapíthatjuk, hogy mindkét, a központi értékeléshez használt teszt megfelelő a gyomorrákok HER2-státusának meghatározására.

\section{DISZKUSSZIÓ}

Évtizedek óta ismert a tény, hogy a gyomorrákos esetek egy részében HER2-pozitivitás igazolható. Ennek a ténynek a gyakorlati jelentősége abban állt, hogy több vizsgálat is kedvezőtlen prognosztikus tényezőnek tartotta ezt a molekuláris sajátosságot $(2,5,6)$. A HER2 elleni célzott terápia elérhetôvé válásával azonban felértékelődött és átértékelődött a gyomorrák HER2-státusa meghatározásának jelentősége (1). A klinikai vizsgálatok eredményei egyértelmúen azt mutatták, hogy a beválasztott HER2-génamplifikált gyomorrákos betegek közül azok esetében volt hatékony a trastuzumab-terápia, akiknél legalább $2+$ intenzitású proteinexpresszió is jelen volt a daganatban. Ez jelentős eltérés az emlőrákokhoz képest, ahol önmagában a HER2 gén amplifikációja is elegendő a trastuzumab-terápia hatékonyságához. Fontos megfigyelése volt továbbá a Herceptin törzskönyvezési vizsgálatának az is, hogy az intestinalis, ill. kevert szövettani típusú daganatok esetében volt igazán kedvező a gyógyszer klinikai hatása (1). Megállapítható, hogy a HER2-meghatározás gyomorrákra történő módosítása patológiailag releváns, ezért át kell venni a hazai vizsgálatok során is ezt a módszertant. Nagyon fontos az irányelvek pontos betartása, ezt megfelelő továbbképzéssel minden HER2-diagnosztikát végző laboratóriumnak el kell sajátítania. Célszerûnek

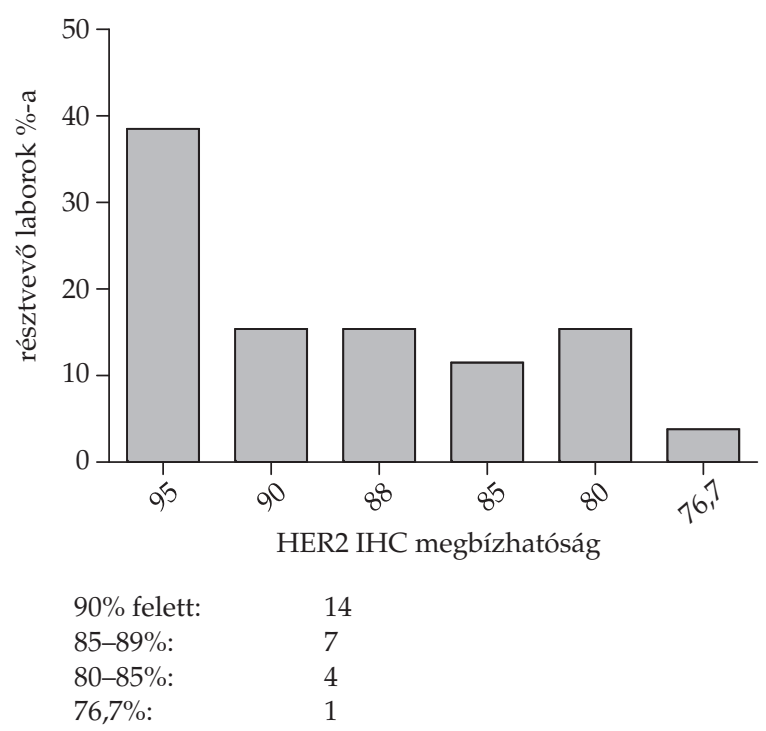

4. ábra. A HER2-körvizsgálatban résztvevő patológiai osztályok eredményessége a TMA metszeten elvégzett immunhisztokémiai reakció értékelése alapján, a standarddal való összevetés után 
tûnik, ami emlőrák esetében is fontos követelmény kellene, hogy legyen, hogy megfelelően validált metodológiával történjen a HER2-proteinexpresszió meghatározása. Jelenleg két antitest áll rendelkezésre klinikai diagnosztikus tesztként, ezek közül az egyik automata rendszerre kidolgozott, a másikat bármilyen rendszerrel lehet alkalmazni. Mielőtt egy laboratórium a saját házi módszerének alkalmazását végzi rutinszerûen klinikai (biopsziás vagy mûtéti) anyagon, célszerû validálni a módszert a standardnak tekinthető antitestekhez képest.

Az in situ hibridizációs vizsgálat a gyomorrák diagnosztikájának még egy kissé kidolgozatlan területe. Elsősorban a poliszómia gyakorisága miatt a kettős jelölés módszerét javasolt alkalmazni, és a génamplifikáció kritériumának a CEP17-hez képest kétszeres HER2-kópiaszámot kell tekinteni $(1,3,7)$. Általánosan az a szabály, hogy a 20 legmagasabb kópiaszámot mutató sejt esetében végezzük a mérést, és amennyiben kettőhöz nagyon közel álló HER2/CEP17 arányt kapunk, újabb 20 sejtet kell leszámolni.

Klinikopatológiailag fölmerül a kérdés, hogy mútéti preparátumok esetében hány blokkból történjen meg a vizsgálat. A gyomorrák heterogén HER2-expressziója miatt célszerú a vizsgálatot akkor megismételni, ha negatív eredményt kaptunk az első kijelölt blokkban, ilyenkor a daganat másik területének vizsgálata indokolt. Endoszkópos minták esetében, ahol általában csak néhány kis minta áll rendelkezésre, nincs mód másik mintákon megismételni a HER2-vizsgálatot. A gyomorrák HER2-meghatározásának elterjedésével nyilvánvalóan revízió alá kell venni az endoszkópos gyakorlatot, nevezetesen azt a kérdést, hogy hány mintát szükséges venni inoperábilis gyomorrák esetén. A Magyar Patológusok Társasága és a Patológiai Szakmai Kollégium javaslata ebből a szempontból az, hogy a nemzetközi ajánlásokban meghatározott minimális biopsziaszámot kellene követni, ami 4-5 mintát jelent daganatonként.

Összefoglalva azt mondhatjuk, hogy a gyomorrák célzott, HER2 elleni terápiájának bevezetése a klinikai gyakorlatba nagy előrelépést jelent a gyomorrákok kezelése szempontjából. Ez azonban csak úgy válhat igazán sikeressé, ha a HER2-meghatározás módszertana megfelelően validált, szigorú kritériumok alapján történik. Különösen fontos ezt azért is szem előtt tartani, mert a gyomorrákok esetében viszonylag gyakran csak- is és kizárólag biopsziákból történik a diagnosztika, amelyek esetében a HER2-meghatározást különösen tapasztalt patológusoknak, és gyakorlott, standardizált módszereket alkalmazó, rendszeresen minőségellenőrzött laboratóriumoknak szabad csak végeznie.

\section{KÖSZÖNETNYILVÁNÍTÁS}

A Roche Magyarország Kft. adminisztratív és anyagi támogatást biztosított mind a retrospektív vizsgálat elvégzéséhez, mind a körvizsgálat lebonyolításához. Az elemzéseket végző patológusok honoráriumban részesültek. A szerzők köszönetüket fejezik ki Sklánitzné Samodai Erikának és Pekár Magdolnának az immunhisztokémiai és in situ hibridizáció reakciók elvégzéséért, valamint a HER2 körvizsgálatban résztvevő patológiai osztályoknak.

\section{IRODALOMJEGYZÉK}

1. Bang YJ, Van Cutsem E, Feyereislova A, et al. ToGA Trial Investigators. Trastuzumab in combination with chemotherapy versus chemotherapy alone for treatment of HER2-positive advanced gastric or gastro-oesophageal junction cancer (ToGA): a phase 3, openlabel, randomised controlled trial. Lancet 376:687-697, 2010

2. Barros-Silva JD, Leitão D, Afonso L, et al. Association of ERBB2 gene status with histopathological parameters and disease-specific survival in gastric carcinoma patients. Br J Cancer 100:487-493, 2009

3. Hofmann M, Stoss O, Shi D, et al. Assessment of a HER2 scoring system for gastric cancer: results from a validation study. Histopathology 52:797-805, 2008

4. Kásler M, Ottó Sz. Európai és hazai kihívások az onkológiában. Magyar Onkológia 52:21-33, 2008

5. Liang Z, Zeng X, Gao J, et al. Analysis of EGFR, HER2, and TOP2A gene status and chromosomal polysomy in gastric adenocarcinoma from Chinese patients. BMC Cancer 8:363, 2008

6. Myllykangas S, Junnila S, Kokkola A, et al. Integrated gene copy number and expression microarray analysis of gastric cancer highlights potential target genes. Int J Cancer 123:817-825, 2008

7. Rüschoff J, Dietel M, Baretton G, et al. HER2 diagnostics in gastric cancer - guideline validation and development of standardized immunohistochemical testing. Virchows Arch 457:299-307, 2010

8. Tímár J. A gyomorrák prognosztikus pathológiája. In: Gastro Update 2008. Szerk.: Asztalos I, Metzger P, Papp J. Gastro Update Alapítvány, Budapest 2008, pp. 162-165

9. Vauhkonen M, Vauhkonen H, Sipponen P. Pathology and molecular biology of gastric cancer. Best Pract Res Clin Gastroenterol 20:651-674, 2006 